\title{
BREEDING AND GROWTH OF WHITING (GADUS MERLANGUS L.) IN ISLE OF MAN WATERS
}

\author{
By A. B. Bowers \\ Marine Biological Station, Port Erin
}

(Plate I and Text-figs. I-6)

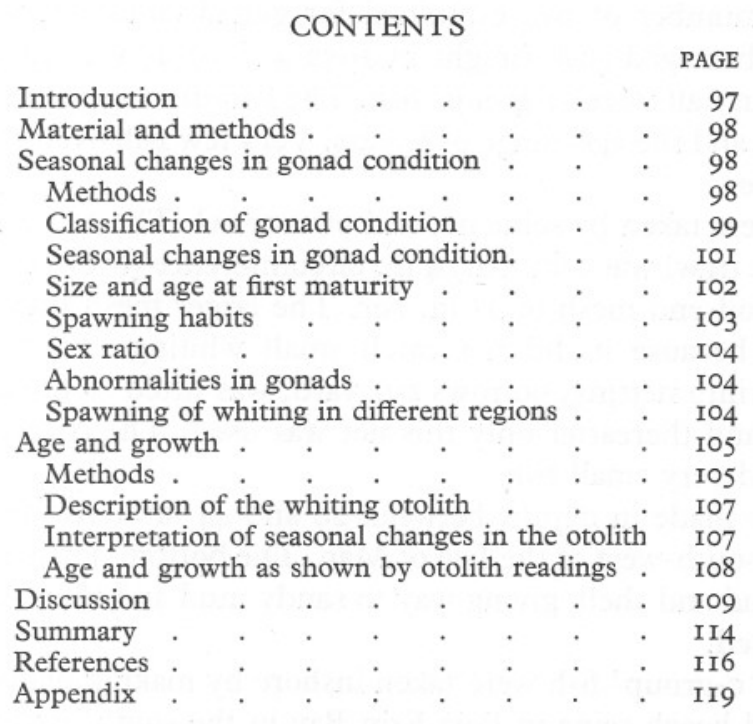

\section{INTRODUCTION}

The whiting (Gadus merlangus L.) is an abundant food fish in waters to the west and south-west of the Isle of Man. As the stock is at times subject to intensive fishing it seemed desirable to study this species and possibly ascertain the effect of commercial exploitation on the biology of the fish.

The spawning period of the whiting in the Irish Sea has been investigated by Scott (1913, I9I4) and Bal (I94I); they deduced from counts of pelagic eggs that the spawning time extended from February to May or June, and that peak spawning occurred in April. The present investigation on seasonal changes in gonad condition of adult Manx whiting supports their conclusions. 
Age and growth determinations have not previously been made on whiting from the Irish Sea.

This work was started at the suggestion of the late Prof. J. H. Orton, F.R.S., who gave much advice and encouragement. I am indebted to Dr J. W. Jones and $\mathrm{Mr}$ J. S. Colman for criticizing the manuscript.

\section{MATERIAL AND Methods}

The whiting examined were caught between December 1948 and December I95I; few fish were taken between June and November in any one year. Three or four samples per month were taken in the seven months from December to June, which include the pre-spawning and main spawning period. The number of fish examined for gonad condition was over 3000 , and the number aged (fish caught in 1950 and I95I) was a little over 2000, of which about half were ' $I$ group' fish. The length-range of the fish sampled was $7-52 \mathrm{~cm}$. and the age-range $0-8$ years. Very few fish over 4 years old were taken, however.

The fish were taken by seine net and otter trawl. The cod-end mesh of the seine and one trawl was I in. bar, 4 in. circumference (Steven, I950), another trawl had a cod-end mesh of $2 \frac{1}{2}$ in. bar. The larger mesh was not used after March 1949 because it did not catch small whiting. In November 1950 a cover of shrimp netting, 90 rows per yard, was fitted to the cod-end of the trawl in use and thereafter only this net was used. The covered trawl effectively retained very small fish.

Hauls were made in depths between 20 and 44 fathoms $(36.6-80.5 \mathrm{~m}$.) to the west and south-west of the Isle of Man. The bottom deposit in 20 fathoms was sandy mud and shell, giving way to sandy mud and then soft mud as the depth increased.

Immature 'o-group' fish were taken inshore by making hauls at night with a fine-meshed beach seine in Port Erin Bay in the south of the Isle of Man.

\section{Seasonal Changes in Gonad Condition}

\section{Methods}

Trawl hauls were of short duration, and all the whiting from a haul were examined. When more than 600 fish were taken by seining, random samples of 100-200 fish were examined, otherwise complete catches were used. All fish were examined fresh, i.e. within $24 \mathrm{hr}$. of capture.

Each fish was measured to the nearest whole centimetre below its actual 'total length' (i.e. lengths from $X \mathrm{~cm}$. up to but not including $X+\mathrm{I} \mathrm{cm}$. were all recorded as $X \mathrm{~cm}$.; the mid-point of the length group was taken as $X \cdot 5 \mathrm{~cm}$.). Total length is defined as the length from the point of the upper jaw to the 
end of the longest fin ray of the tail fin, which was drawn into line with the main axis of the fish.

Sex was determined macroscopically and a 'gonad stage' assigned according to an arbitrary classification into seven stages, similar to that devised by Hjort (I9I0) for international herring research.

\section{Classification of Gonad Condition}

Bull (I928) used a five-stage maturity scale for whiting, modified from Graham's (I924) classification of cod gonads. Bull's classification has been amplified to avoid the use of intermediate stages, and extended to include
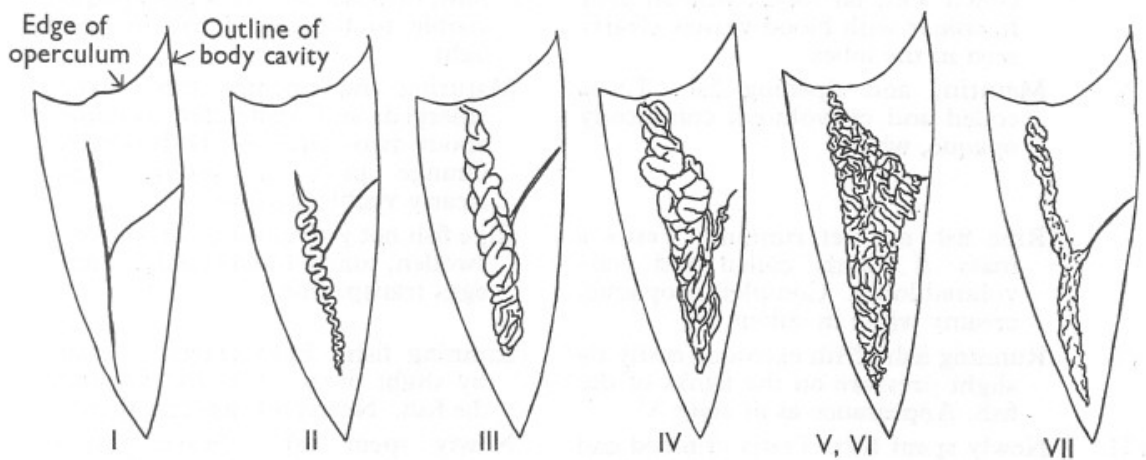

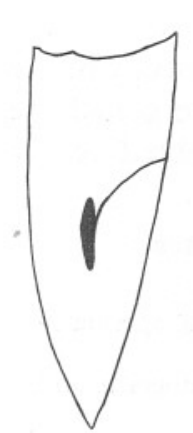

I

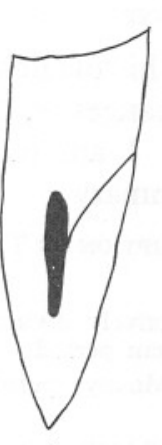

II

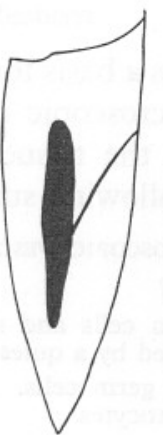

III

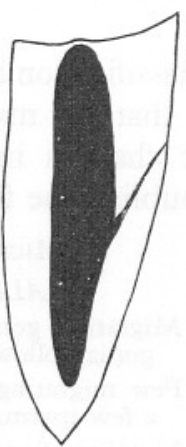

IV

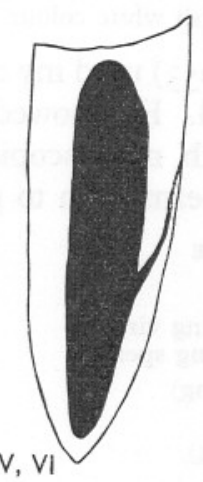

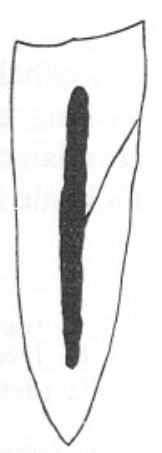

VII

Text-fig. I. Changes in size of gonad in relation to the body cavity at different stages of maturity. Upper row: testis; lower row: ovary.

a separate stage for newly spent gonads of both male and female whiting. The typical appearance of the gonad at each of the maturity stages employed in this investigation is described below. The relation between gonad size and size of the body cavity, and the shape of the gonad at each stage is shown in Text-Fig. I. 


\section{STAGE \\ I Immature virgin fish. Testis a very thin narrow translucent ribbon lying along an unbranched blood vessel}

II Maturing virgins or recovered spents in resting condition. Testis slightly lobed and lightly coiled. Opaque white at anterior end, transparent at posterior at first, later uniformly white

III Maturing and ripening fish. Length of testis about three-quarters length of body cavity. Testis more strongly coiled with fat lobes, whitish grey in colour with blood vessels clearly seen in the lobes

IV Maturing and ripening fish. Testis coiled and convoluted, completely opaque, white

Ripe fish not yet running. Testis a mass of tightly coiled and convoluted lobes. Completely opaque, creamy white in colour

VI Running fish. Milt extruded easily by slight pressure on the flanks of the fish. Appearance as at stage V

VII Newly spent fish. Testis crinkled and shrunken, rather bloodshot. Yellowish white colour
Female

Immature, virgin fish. Ovaries very small, not more than one-fifth of the length of the body cavity, usually less than $2 \mathrm{~cm}$. long. Elongated sausage shape. Whitish, translucent. Eggs microscopic

Maturing virgins or recovered spents in resting condition. Ovary not more than one-third length of body cavity, torpedo-shaped. Colour varying from wine-coloured, translucent, to dull orange

Maturing and ripening fish. Ovary not more than one-half length of body cavity. Colour pink, pinkish buff, or flesh colour. Eggs opaque, visible to the naked eye in good light

Maturing and ripening fish. Ovary enlarged and distended occupies about two-thirds of body cavity. Orange pink in colour. Eggs clearly visible, opaque

Ripe fish not yet running. Ovary very swollen, tunica bursts easily. Some eggs transparent

Running fish. Eggs extruded easily by slight pressure on the flanks of the fish. Nearly all eggs transparent

Newly spent fish. Ovary pinkish white, flaccid, shrunken, with some residual eggs

Gokhale (I953) used my classification as a basis for histological study of the whiting gonad. He showed that the macroscopic changes in the gonad are correlated with microscopic changes in the tissue. I am indebted to Dr Gokhale for permission to publish the following summary:

STAGE

I $\left\{\begin{array}{l}\text { developing virgin } \\ \text { recovering spent }\end{array}\right\}$
III (developing)

IV (maturing)

V (full)

VI (running)

VII (spent)

$$
\begin{aligned}
& \text { II }\left\{\begin{array}{l}
\text { developing } \\
\text { virgin }
\end{array}\right. \text {, } \\
& \text { III (developing) }
\end{aligned}
$$

\section{Microscopic Description of Tissue}

$$
M A L E
$$

Migrating germ cells and actively dividing spermatogonia, followed by a quiescent period

Few migrating germ cells. Mostly spermatogonia and a few spermatocytes

Number of spermatocytes very high; a few spermatozoa towards the centres of the lobules

Spermatogenesis complete; number of spermatozoa progressively greater

Lobules almost empty; relict sperm being resorbed. Some migrating germ cells along the interlobular wall

\section{FEMALE}

Large number of oogonia, presynaptic and post-synaptic oocytes

Oocytes larger: number of nucleoli increased. No oolemma in early stages but indications of oolemma forming in late stage III 
IV (maturing)

$$
\begin{aligned}
& \text { V (full) } \\
& \text { VI (running) } \\
& \text { VII (spent) }
\end{aligned}
$$

VII-II (spent-recovering)

II (recovered)
Marked increase in size of oocytes. Yolk vesicles present in oocytes; oolemma present. Some immature ova undergoing degeneration

Eggs much grown. Some follicles empty; mature eggs lying in central cavity

Few mature eggs remain, those present undergoing resorption; formation of corpora lutea. Large cavities in the tissue resulting from breakdown of interovular tissue. Loose granulosa cells and blood cells in tissue. Tunica thicker than previous stage

Resorption of eggs nearly complete. Yellow patches as remnants of corpora lutea; formation of cell pearls. Oogonia and oocytes occupy the rest of the ovary. Tunica thick

As virgin stage II, except that tunica thick

Gokhale's work showed that the spent-recovering and recovered spawner stages could have been distinguished from the developing virgin stage II in the female whiting, since the yellow patches described for stage VII-II are visible to the naked eye, and the thick tunica in stage II (recovered) can be felt between the fingers. No reliable macroscopic difference was found to distinguish maturing virgins from recovered spents in the male.

\section{Seasonal Changes in Gonad Condition}

Gonads were classified by their macroscopic appearance in each month except July, when no samples were available. Data are given in Table I and the seasonal changes observed are shown diagrammatically in Text-fig. 2. Immature virgin fish (stage I), which were found throughout the year, are not included in the table.

The records showed that some fish began to develop towards maturity as early as November, but the gonads of most fish were then in the recovered or resting state (stage II) and showed little or no change in size or appearance until January. From January until April there was a steady advance towards maturity, and in April ripe fish (stage V) were dominant. In May and June spent and recovering fish (stages VII and II) were the most common. Of the few fish examined from August to October the greater part were recovering or recovered from spawning, a few were spent, and none had maturing gonads. The large range in gonad condition in each month from February to June shows that there is wide variation in the time of the year at which different fish mature.

Running fish (stage VI) were taken between February and June inclusive; the spawning season thus extends over at least 5 months of the year. The small number of fish caught in gonad stage VI suggests that the actual spawning of an individual fish lasts only a short time, so that the chances of catching fish at this stage are low. The intensity of spawning in each month throughout the period is shown in Table II by a comparison of the number of ripe and running fish with the total number of potential spawners (i.e. fish with gonads 
developing towards maturity, or spent). Most of the fish spawn or are ready to spawn in March and April and spawning is virtually over by June. A very few spent fish, however, were found in the early winter (Table I), which suggests that there may be a small amount of late spawning.

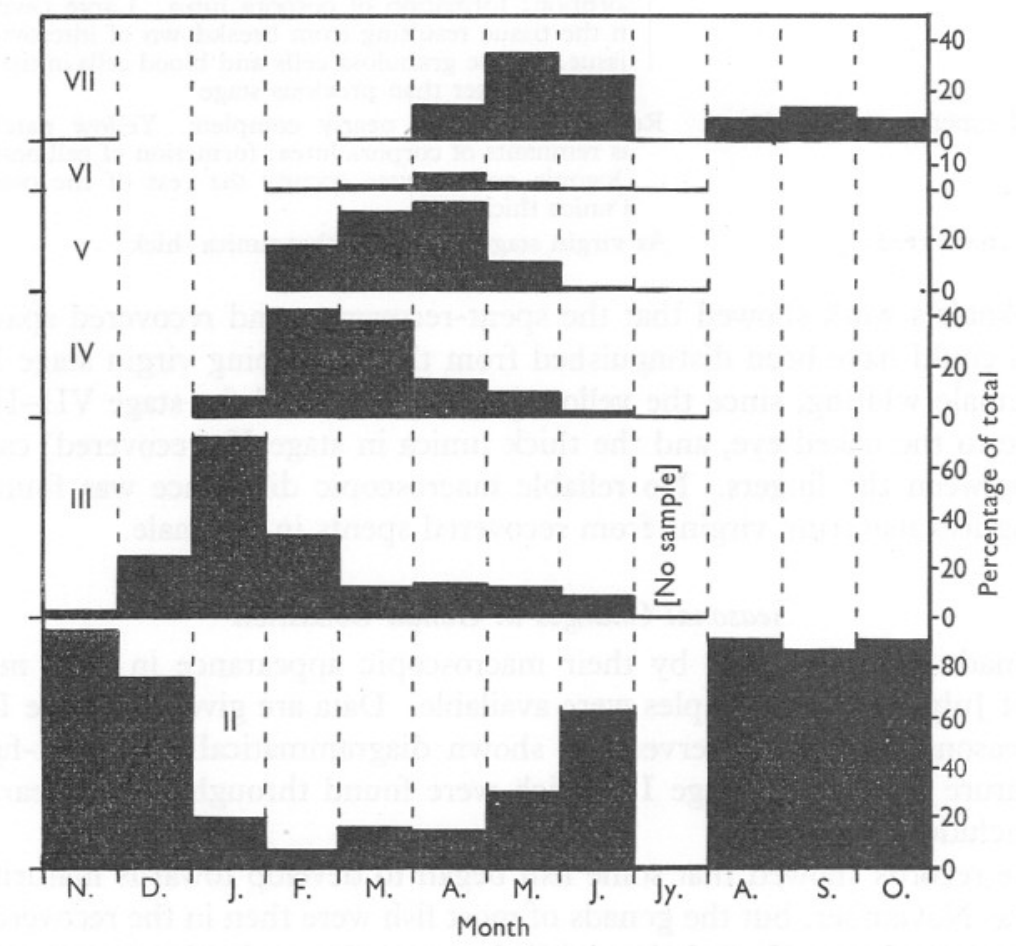

Text-fig. 2. Monthly percentage of adult fish with gonads at each maturity stage.

Spent gonads appear to recover rapidly in the whiting, as by June most of the fish had gonads in the resting stage (II). This was reflected in the marked fall in the number of spent fish caught in June (Table I). 'Recovery' implies the complete resorption of residual eggs and sperm and the change in general appearance from the shrunken, rather bloodshot spent gonad to the firm, clear gonad described above for stage II.

\section{Size and Age at First Maturity}

The smallest Manx whiting found in an advanced state of maturity, i.e. stages V, VI, or VII, were a male of $19 \mathrm{~cm}$. total length and a female of $21 \mathrm{~cm}$.

No female fish in age-group I was found with gonads more mature than stage II. Ripe fish were commonly found in age-group 2; on the other hand, no immature virgin fish were found in age-group 3 . It therefore appears that 
Table I. Number of Fish in each Gonad Stage in each Month

(IMMATURE VIRGINS NOT INCLUDED)

(Figures in brackets are values derived from very small samples. The predominating gonad stage is in bold type.)

\begin{tabular}{|c|c|c|c|c|c|c|c|c|}
\hline \multirow[b]{2}{*}{ Month } & & \multicolumn{6}{|c|}{ Gonad stage } & \multirow{2}{*}{$\begin{array}{l}\text { No. of fisl } \\
\text { examined }\end{array}$} \\
\hline & & II & III & IV & $\mathrm{V}$ & VI & VII & \\
\hline Nov. & No. of fish & 64 & 2 & - & - & - & I & 67 \\
\hline Dec. & $\begin{array}{l}\% \text { of total } \\
\text { No. of fish }\end{array}$ & $\begin{array}{l}95 \cdot 5 \\
40\end{array}$ & $\begin{array}{r}3 \\
13\end{array}$ & $\frac{-}{-}$ & - & - & $\stackrel{I \cdot 5}{-}$ & $\overline{53}$ \\
\hline & $\%$ of total & $75 \cdot 5$ & $24 \cdot 5$ & - & - & - & - & \\
\hline Jan. & $\begin{array}{l}\text { No. of fish } \\
\% \text { of total }\end{array}$ & $\begin{array}{l}19 \\
20\end{array}$ & $\begin{array}{l}68 \\
72\end{array}$ & $7 \cdot 7 \cdot 5$ & 二 & 二 & 二 & 94 \\
\hline Feb. & $\begin{array}{l}\text { No. of fish } \\
\% \text { of total }\end{array}$ & $\begin{array}{r}16 \\
7\end{array}$ & $\begin{array}{l}73 \\
33\end{array}$ & $\begin{array}{l}92 \\
41 \cdot 5\end{array}$ & $\begin{array}{l}39 \\
17.5\end{array}$ & $\begin{array}{l}\mathrm{I} \\
0.5\end{array}$ & 二 & 221 \\
\hline March & No. of fish & I2I & 88 & 273 & 228 & 13 & $\overline{7}$ & $\overline{730}$ \\
\hline & $\%$ of total & 16.5 & I2 & $37 \cdot 5$ & $3 x$ & 2 & I & \\
\hline Apr. & $\begin{array}{l}\text { No. of fish } \\
\% \text { of total }\end{array}$ & $\begin{array}{l}49 \\
15\end{array}$ & $\begin{array}{l}45 \\
13.5\end{array}$ & $\begin{array}{l}50 \\
15\end{array}$ & $\begin{array}{r}\text { II } 7 \\
35\end{array}$ & $\begin{array}{r}24 \\
7\end{array}$ & $\begin{array}{l}47 \\
\mathrm{I} 4\end{array}$ & $33^{2}$ \\
\hline May & No. of fish & 130 & $5 \mathrm{I}$ & 44 & 48 & I2 & I44 & 429 \\
\hline & $\%$ of total & 30 & $\mathrm{I} 2$ & IO & II & 3 & 33.5 & \\
\hline June & No. of fish & $\begin{array}{l}87 \\
62\end{array}$ & $\begin{array}{l}12 \\
8.5\end{array}$ & $\begin{array}{l}3 \\
2\end{array}$ & I & $\begin{array}{l}\text { I } \\
\text { I }\end{array}$ & $\begin{array}{l}36 \\
25.5\end{array}$ & 140 \\
\hline July & & & & No & ample & & & \\
\hline Aug. & No. of fish & Io & - & - & - & - & I & II \\
\hline & $\%$ of total & (9I) & - & - & - & & (9) & - \\
\hline Sept. & $\begin{array}{l}\text { No. of fish } \\
\% \text { of total }\end{array}$ & $\begin{array}{l}20 \\
(87)\end{array}$ & $\overline{-}$ & 二 & 二 & 二 & (13) & 23 \\
\hline Oct. & $\begin{array}{l}\text { No. of fish } \\
\% \text { of total }\end{array}$ & $\begin{array}{l}\text { I0 } \\
\text { (9r) }\end{array}$ & 二 & 二 & 二 & 二 & $\begin{array}{l}\text { I } \\
(9)\end{array}$ & II \\
\hline
\end{tabular}

Table II. Monthly Percentage of Ripe and Running Fish in the Adult Stock throughout the Spawning Period

$\begin{array}{lcccccc}\quad \text { Month } & \text { Jan. } & \text { Feb. } & \text { Mar. } & \text { Apr. } & \text { May } & \text { June } \\ \text { No. of fish examined } & 94 & 22 \mathrm{I} & 730 & 332 & 429 & \text { I } 40 \\ \text { No. of ripe and running fish } & 0 & 40 & 24 \mathrm{I} & \mathrm{I} 4 \mathrm{I} & 60 & 2 \\ \% \text { of total } & 0 & \mathrm{I} 8 & 33 & 42 \cdot 5 & \mathrm{I} 4 & \mathrm{I} \cdot 5\end{array}$

around the Isle of Man female whiting generally spawn for the first time at the end of their second year of life, and by the end of the third year (fish which are just entering age-group 3) all normal females are mature. Male whiting may spawn at the end of their first year of life: evidence of spawning or maturity was found in approximately $4 \%$ of the age-group I male fish taken during the spawning season. Practically all males of age-group 2 spawn.

\section{Spawning Habits}

No evidence was obtained of segregation of ripe fish into spawning shoals. From February until July fish in all stages of maturity were found together 
over all the area investigated. There are no records in the literature that special spawning shoals are formed. Ripe fish continue to feed.

The larger fish matured earlier in the season than the small fish of spawning size, and presumably spawned earlier (see Table III). In February and March, for example, the maturing females between 20 and $30 \mathrm{~cm}$. long, most of them fish of age-group 2 ripening for the first time, were on average in a less advanced stage of gonad development than the females over $30 \mathrm{~cm}$. long, most of which had spawned at least once before. Similar differences in time of ripening can be demonstrated among male fish of different length groups.

Records of gonad development in fish of known age suggest that fish in age-group 3 spawned earlier than did those in age-group 2, but the evidence is not conclusive; it would appear that size is more important than age in determining the time of maturation.

Table III. Number of Fish at each Stage of Gonad Maturity, SHOWN FOR DIFFERENT LENGTH-GROUPS

(Data for February and March I949 and I950. The most common stage of maturity is shown in heavy type.)

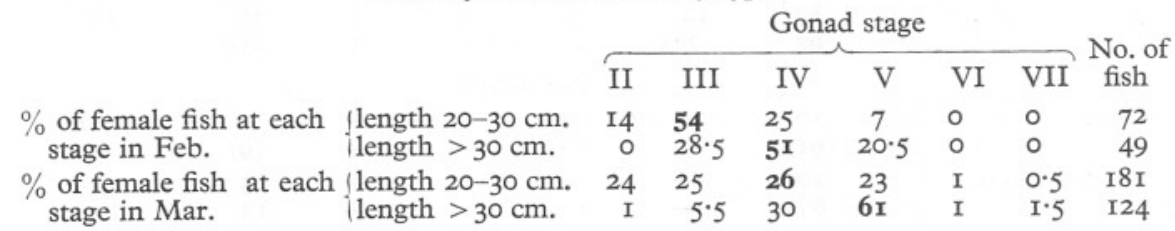

Sex Ratio

Of 3 II 8 fish sexed, of length range I $2-52 \mathrm{~cm}$., $52 \cdot 8 \%$ were male, $47 \cdot 2 \%$ female. Fulton ( 1892 ) found that $32 \cdot 2 \%$ of the whiting he examined were male, $67.8 \%$ female. The average size of Fulton's fish was greater than that of mine, and presumably he had more large fish; it will be shown later that the larger fish are predominantly female.

\section{Abnormalities in Gonads}

Two female fish were observed, each with one ovary developing normally and the other atrophied. One fish was $27 \mathrm{~cm}$. long with the normal ovary in gonad stage III, the other $30 \mathrm{~cm}$. long with the normal ovary ripe, gonad stage V. No internal parasites which might have caused the abnormality were found in either fish.

Hermaphrodite whiting are rare (Desbrosses, 1948): none were seen among 3II8 Manx whiting.

\section{Spawning of Whiting in Different Regions}

The spawning behaviour of the Manx whiting is intermediate between that of fish from the northern part of the geographical range of the species and fish from the southern part of the range. This is shown in relation to the spawning 
season, the time of maximum spawning activity, and age and length at first maturity.

Spawning of the whiting occurs progressively later as the latitude increases. Table IV shows that there is a variation of 4 months in the onset of spawning in different regions of western Europe. Desbrosses (I945) showed that variation in spawning time is closely connected with sea temperature; in the Irish Sea gonad development is greatest when sea temperatures are low, in February and March, and spawning is at a maximum in April when sea temperature starts to rise. From Table IV it appears that in many areas maximum spawning occurs as the temperature rises after the winter minimum.

Age and length at maturity increase from south to north of the species range. The data for Manx whiting agree closely with those for Scottish fish (Fulton, I892, I901) and are a good fit in a table prepared by Desbrosses (I945) to show the geographical variation.

\section{AGE AND GROWTH}

\section{Methods}

Age was determined by means of otoliths, of which less than I $\%$ had to be rejected as unreadable. Some scales were also examined, but the interpretation of many of these was doubtful because secondary growth rings were common and difficult to distinguish from true growth rings.

From March I950, otoliths were taken from the whiting caught for the study of gonads. Adequate samples of offshore fish were obtained from March to June 1950, and from January to June I95I. Most of the samples were taken at a time of year when there is little growth in length of the fish.

Fresh fish were measured and sexed as described on p. 98. Otoliths were then removed in the following way: the fish was laid on its side, the blade of a strong scalpel was slipped under the operculum and drawn forward dorsally towards the point of the snout, thereby cutting through the skull. The otolith thus exposed was removed, undamaged, by means of forceps. It was found convenient to remove both large otoliths and place those from each fish in a separate labelled envelope. The envelopes containing otoliths from each sample were stored together in a sealed jar of spirit.

Otoliths were prepared for examination by removal of the remains of the sacculus (if present), followed by a wash in clean $95 \%$ spirit and immersion for a few minutes in pure creosote until the rings showed clearly (Johnston, I938). Thick otoliths were found to be more easily read after the convex surface had been ground slightly with carborundum (Menon, I950).

The otoliths were examined in a matt black dish by reflected light. It was found that any magnification confused rather than clarified the reading (cf. Hickling, I933), and all age assessments were made after examination with the naked eye. 


\section{Table IV. Spawning Period of the Whiting in Different Localities}

Region
Iceland
Iceland
Shetland
Scotland
Scotland, E. (Firth of Forth)
Scotland, W. (Firth of Clyde)
Ireland, W.
Irish Sea (Manx Waters)
Irish Sea (Manx Waters)
Irish Sea (Manx Waters)
Heligoland
Heligoland
Plymouth area
Plymouth area
French Atlantic coast

\begin{tabular}{cl}
$\begin{array}{r}\text { Approx. } \\
\text { latitude }\end{array}$ & \multicolumn{1}{c}{ Authority } \\
$63-65^{\circ} \mathrm{N}$. & Schmidt (1909) \\
& \\
$63-65^{\circ} \mathrm{N}$. & Ehrenbaum (1936) \\
$60-61^{\circ} \mathrm{N}$. & Damas (1909) \\
$56-58^{\circ} \mathrm{N}$. & Fulton (1892) \\
$56^{\circ} \mathrm{N}$. & Williamson (1895) \\
$56^{\circ} \mathrm{N}$. & Williamson (1899) \\
$52-56^{\circ} \mathrm{N}$. & Holt (1891, 1893) \\
$54^{\circ} \mathrm{N}$. & Scott (1913, 1914) \\
$54^{\circ} \mathrm{N}$. & Bal (194I) \\
$54^{\circ} \mathrm{N}$. & Present investigation \\
$54^{\circ} \mathrm{N}$. & Heinke \& Ehrenbaum (1900) \\
$54^{\circ} \mathrm{N}$. & Heinke (1905) \\
$50^{\circ} \mathrm{N}$. & Cunningham (1889) \\
$50^{\circ} \mathrm{N}$. & Clark (1920)
\end{tabular}

\begin{tabular}{|c|c|c|}
\hline $\begin{array}{l}\text { Method of } \\
\text { assessment }\end{array}$ & $\begin{array}{l}\text { Extent of } \\
\text { spawning period }\end{array}$ & $\begin{array}{c}\text { Month of } \\
\text { maximum spawning }\end{array}$ \\
\hline $\begin{array}{l}\text { Running fish and } \\
\text { presence of eggs }\end{array}$ & $\begin{array}{l}\text { May (or earlier)- } \\
\text { Mid July }\end{array}$ & - \\
\hline Presence of eggs & - & End of May \\
\hline Eggs and young larvae & Up to Sept. & - \\
\hline Ripe fish & Mar.-Aug. & Apr. \\
\hline Abundance of eggs & Mar.-June & Apr. \\
\hline Abundance of eggs & Feb.-Aug. & Apr. \\
\hline Abundance of eggs & Mar.-June & Mar., Apr. \\
\hline Abundance of eggs & Feb.-May & Early Apr. \\
\hline Abundance of eggs & Feb.-June & Apr. \\
\hline Ripe and running fish & Feb.-June & Apr. \\
\hline Abundance of eggs & Jan.-July & Up to May \\
\hline $\begin{array}{l}\text { Running fish } \\
\text { Abundance of eggs }\end{array}$ & $\begin{array}{l}\text { Mar--June } \\
\text { Jan--May }\end{array}$ & Mar., Apr., May \\
\hline Presence of eggs & Feb. onward & - \\
\hline Abundance of larvae & Feb.-July & - \\
\hline
\end{tabular}

Mean sea

time of max. Annual range of

spawning sea temperature

Feb. Aug.

8 (June)

seb.

$7.5 \quad 5^{-6^{\circ}}$ to ${ }_{10}^{\circ}$

Feb. $6^{\circ}$ to Aug.
$-\quad 12^{\circ}$

6 Feb. $5^{\circ}$ to Aug.

$6 \quad 5^{\circ}$ to ${ }_{12}^{\circ}$

$8 \quad$ Feb. $7^{\circ}$ to Aug.

8 Feb. $9^{\circ}$ to Aug.

$\left.\begin{array}{l}9 \\ 9 \\ 9\end{array}\right\} \quad 7^{\circ}$ to $\mathrm{I}^{\circ}$.

$9 \cdot 5$ (May) $) \quad$ Feb, Aug

$3.5,6,9.5\} \quad \begin{gathered}\text { Feb. } \\ 3^{\circ}\end{gathered}$ to $\begin{gathered}\text { Aug. } \\ 16.5\end{gathered}$

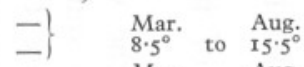

${ }_{46} \cdot 5-48^{\circ} \mathrm{N}$. Desbrosses (1945) Running fish Jan.-June Feb., Mar.

10, $9 \cdot 5$

Mar. Aug.

Temperature data from Bureau du Conseil (1933), Danish Met. Institute (1917), Proudman, Lewis \& Dennis (1937). 


\section{Description of the Whiting Otolith}

The otolith of the whiting is an elongate structure, rounded or obliquely truncated anteriorly and tapering to a point posteriorly. The shape changes considerably with age (see Pl. I). The margin is crenellated. The surface which lies towards the brain is slightly convex in transverse section; the outer surface is flattened. Whiting otoliths are thinner and flatter than those of most other gadoids (Scott, I906).

When examined against a matt black background by reflected light, alternate light (opaque) and dark (translucent) concentric zones can be seen (Pl. I). The core of the otolith may be translucent or opaque, and outside this is an opaque zone in which one or more very narrow translucent bands are often visible. This zone is bounded by a clearly marked, though often complex, translucent band: this will be called the first band and the region inside it called the centre. Alternate opaque zones and translucent bands are visible outside the first band up to a total of seven of each. The larger the fish, the greater is the number of zones and bands which may be seen.

The periphery may be formed of an opaque zone or a translucent band, dependent largely on the season of capture. Since the edge may be very thin, it is sometimes difficult to distinguish whether in fact the edge is opaque or translucent (Wallace, I907; Jones \& Hynes, I950), but with practice it becomes possible.

The relative width of the translucent bands and opaque zones varies considerably in otoliths from different fish (see Pl. IB), but when there are more than three bands on an otolith these bands are narrower and more crowded towards the edge.

The two large otoliths from the same fish nearly always have a similar appearance and give identical readings; about $\mathrm{I} \%$ of the total number of fish examined had one typical otolith and one completely crystalline, showing no alternating bands and zones. In one male fish, $33 \mathrm{~cm}$. long, the left otolith was larger than the right, and had at the edge a translucent band that was not present on the right otolith. This was the only discrepancy of the kind in I088 comparisons of this nature.

\section{Interpretation of Seasonal Changes in the Otolith}

The otoliths of o-group fish taken in July are completely opaque or show a small translucent core with an opaque peripheral area, i.e. only the centre of the otolith has been laid down. In August most of the otoliths show a very narrow translucent edge. Further growth takes place by the addition of opaque material so that the otolith shows a central core bounded by a translucent line, and an opaque edge. The translucent line may become overlaid in older otoliths but can be revealed by grinding the convex surface of the otolith.

The translucent band recognized as the first annual band is broader than 
the translucent line formed in August, and is more clearly marked, although it may be of a double or complex nature, i.e. there may be one or two opaque lines within the translucent band. The annual band is laid down at the edge of the otolith in February, March and April (cf. Desbrosses, I948). By June most of the otoliths show new growth, at the edge of the otolith, which is opaque. Thus the first annual band is formed when the fish has lived one summer and one winter after hatching, and is complete when the fish is about I year old. The actual age of fish in the same age-group may, however, vary by several months because there is a long spawning period, which means that a fish hatched early in the season is already 4 months old by the time the last spawned eggs hatch.

The second and subsequent translucent bands are usually laid down at the edge of the otolith between January and May. Otoliths may have a translucent edge in any month of the year but there is a well-marked maximum in February and March. Thompson (1926) found that the 'winter ring' of narrow sclerites on scales was laid down in February and that new growth started in June; this shows some correspondence with the state of the otolith.

Age estimates were made from the number of bands and zones on the otolith as follows:

Otolith with no translucent band

Otolith showing centre and translucent edge

Otolith showing centre, translucent band and opaque edge

Otolith showing centre, translucent band, opaque zone and translucent edge

Otolith showing centre, two translucent bands with opaque zone between, and opaque edge
Age-group o
Age-group I
Age-group I
Age-group 2
Age-group 2

and so on up to age-group 8 . In short, the fish was allotted to the age-group corresponding to the number of translucent bands seen on the otolith, irrespective of whether the outermost translucent band was at the edge or within an opaque edge.

\section{Age and Growth as shown by Otolith Readings}

Age determinations made by means of otolith readings showed that fish in all age-groups up to 8 were present in the area investigated. Age-groups I to 3 were well represented, but older fish were scarce. Ellis (I950) has suggested that older whiting in the North Sea migrate to deep water. A similar migration might account for the scarcity of fish over 3 years old in the samples examined; I have no evidence on this point, since this investigation was limited to depths of $20-45$ fathoms.

The oldest female fish was $52.5 \mathrm{~cm}$. long and belonged to age-group 8 . The largest male was $47.6 \mathrm{~cm}$. long but the otolith was not readable beyond the seventh band because the outermost markings were confused and indistinct; the fish was certainly more than 7 years old. Four males and four females in age-group 7 were taken. It is possible that older fish would be found in deep 
water, but the age limit of 8 years agrees fairly closely with the observations of Saemundsson (I925), Desbrosses (I948) and Knudsen (I950).

The length distribution of the fish in each age-group is shown in Textfig. 3. Numerical data are given separately for the two years I950 and I95I in the Appendix. The range in length and the mean length at each age-group are shown in Table V. Mean lengths at age-groups 5, 6 and 7 are probably not very reliable because the number of fish in these groups was small.

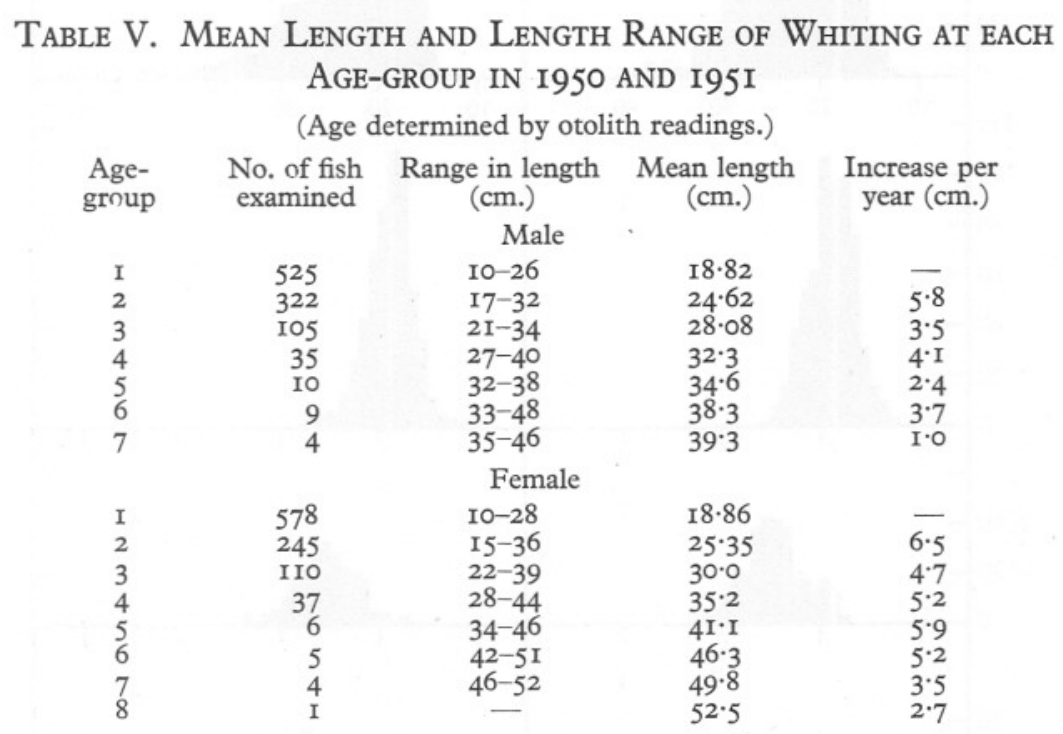

Growth is rapid in both sexes for the first year, and the mean length at the end of the year is between 18 and $19 \mathrm{~cm}$. The range in length is very great. Both male and female fish grow about $6 \mathrm{~cm}$. in the second year. Too few old fish were caught to make an accurate assessment of growth beyond age-group 4, but the available data suggest that the females continue to grow steadily at a rate of 5 or $6 \mathrm{~cm}$. per year until the seventh year (age-group 6) when growth slows down. The male fish grow less than the females after the second year, and the disparity in the mean lengths of the male and female fish at each agegroup increases with age (see Text-fig. 4). Nearly all fish examined of more than $40 \mathrm{~cm}$. total length were females (Text-fig. 3). Similar sexual differences in growth rate have been demonstrated in Icelandic and French Atlantic whiting (Saemundsson, I925; Desbrosses, I948).

\section{Discussion}

The age determinations from otolith readings were based on the assumption that growth rings on the otolith are laid down annually. There is no absolute proof available that this is true (Graham, I928); seasonal records of the state 


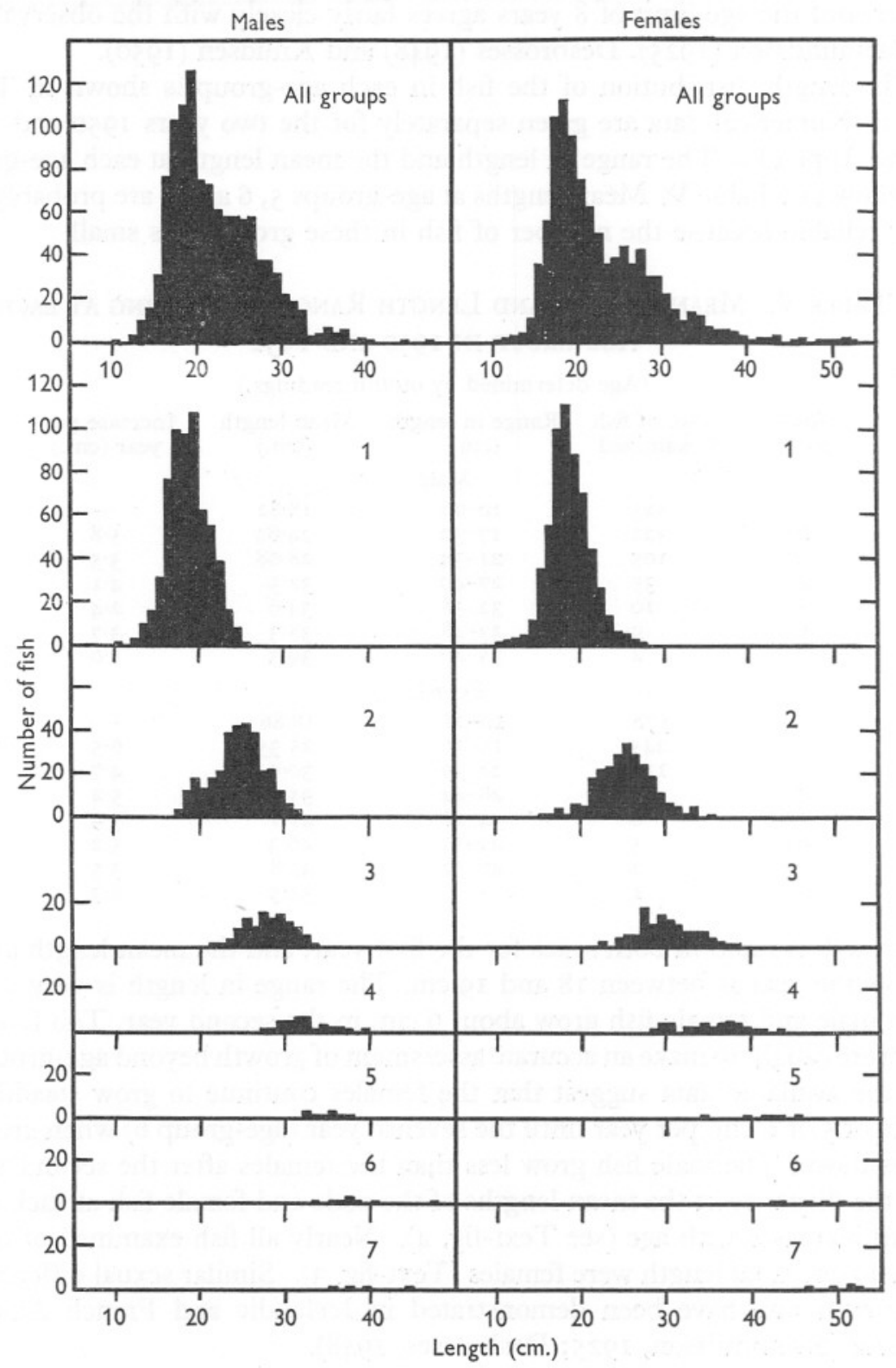

Text-fig. 3. Age and length distribution of offshore whiting, I950 and I951. Age determined by otolith readings. The numbers $\mathrm{I}-7$ refer to the different age-groups. 
of the edge of the otolith were incomplete. Records made in 1950 are shown in Text-fig. 5; those for I95I showed a very similar pattern. The number of

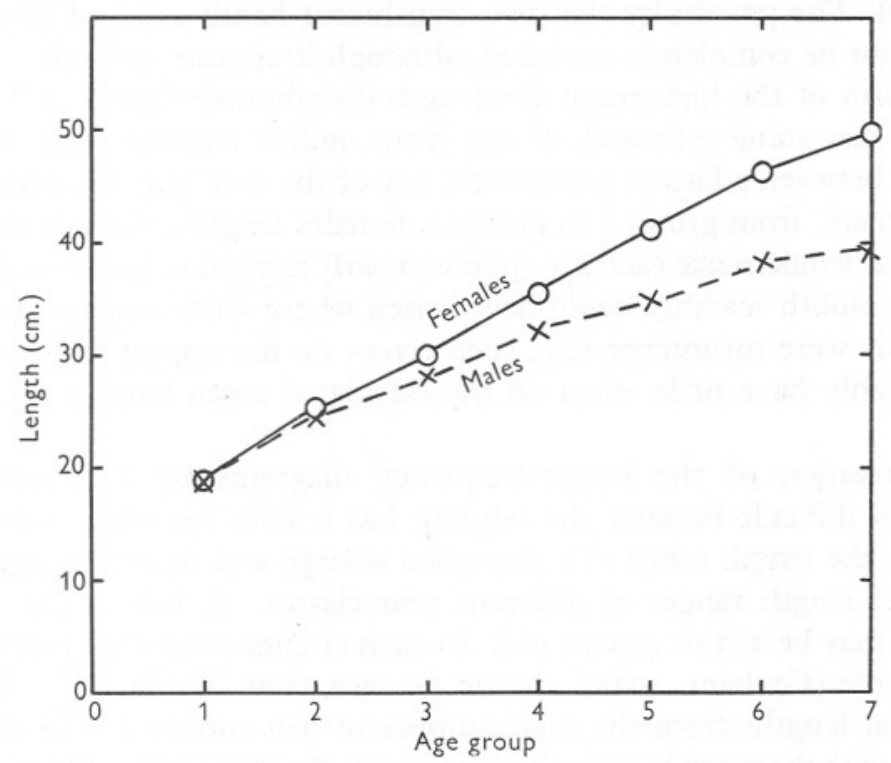

Text-fig. 4. Mean length at each age-group, I950 and I95I.

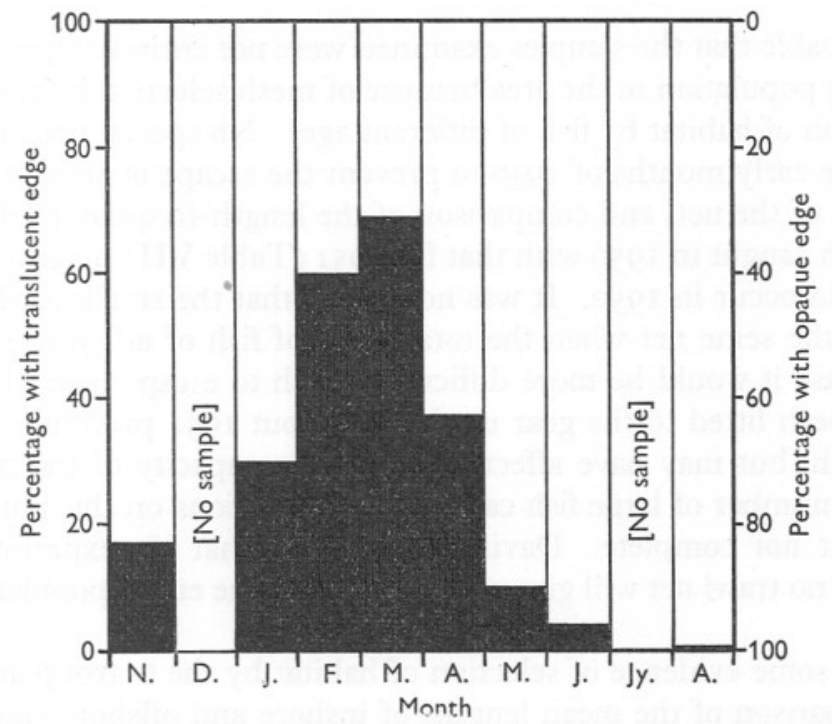

Text-fig. 5. Condition of margin of otolith through the year. Age-groups 2-7.

otoliths with a translucent edge (i.e. those in the course of laying down a translucent year band) shows a peak in February and March when the sea temperature around the Isle of Man is lowest, but there is no complete change-over 
from translucent edge to opaque edge, data are available for only seven months of the year, and the number of specimens examined in November and August was small. The possibility that two translucent bands are laid down in one year cannot be completely excluded, although it appears unlikely.

The form of the histograms for length distribution shown in Text-fig. 3 suggests that some estimates of age from otolith readings may be wrong. Transfer between adjacent groups of a few of the data (e.g. for males, length I 8 and $19 \mathrm{~cm}$. from group 2 to group I, females length $27 \mathrm{~cm}$. from group 3 to group 2) would make each group more nearly normal in length distribution. Errors in otolith readings could have arisen where secondary bands and true year bands were misinterpreted; such errors do not appear to be numerous and probably have little effect on the calculated mean lengths of each agegroup.

Interpretation of the length-frequency diagrams by Petersen's (1895) method is difficult because the whiting has a long spawning period; consequently the length range of a year-class is large and there is a considerable overlap of length ranges of different year-classes. A fish $30 \mathrm{~cm}$. long, for example, may be 2,3 or 4 years old. In such circumstances the method is not very reliable (Graham, I928). It can be seen from Table VII (Appendix) that modal lengths from the total number of fish correspond in only a few instances with the mean lengths of year-groups determined by otolith readings.

It is probable that the samples examined were not entirely representative of the whiting population in the area because of mesh selection by the nets used, and selection of habitat by fish of different ages. No special precautions were taken in the early months of 1950 to prevent the escape of small fish through the meshes of the net, and comparison of the length-frequency table for agegroup I fish caught in 1950 with that for I95I (Table VII) suggests that mesh selection did occur in 1950. It was noticeable that the smallest whiting were present in the seine net when the total catch of fish of all species was large, in which case it would be more difficult for fish to escape from the cod end. The fine mesh fitted to the gear used throughout 195I prevented the escape of small fish, but may have affected the fishing capacity of the net so as to reduce the number of large fish caught. Investigations on this point are proceeding but not complete. Davis (1934) states that his experiments show clearly that no trawl net will give a true sample of the entire population on any ground.

There is some evidence of selection of habitat by the o-group and I-group fish. Comparison of the mean lengths of inshore and offshore catches of the I95I brood of whiting (Text-fig. 6) shows that the offshore fish were larger than those inshore. Great care was taken to avoid mesh selection by the gear used, and samples were numerically large. Scattered observations in earlier years fit well with the $195 \mathrm{I}-52$ data shown in the figure (unpublished work at 
Port Erin). Most of the small I-group whiting caught offshore in spring were at the shallowest limit of the fishing ground (20-25 fathoms). I-group fish appeared sporadically in sandy bays inshore throughout the summer and autumn. The area between the bays and the offshore fishing ground is too rough for net fishing and there is therefore insufficient evidence to assess the relation between the depth of water and the size of the I-group fish, or to determine the movements of the fish. The relation and interchange between the inshore shoals and the offshore stock is complex and requires more study, but it seems likely that there is a movement of some young fish away from inshore waters throughout the winter months from September onwards. The offshore stock is probably recruited gradually from the inshore shoals; and the larger fish move offshore in greater numbers than do the smaller fish.

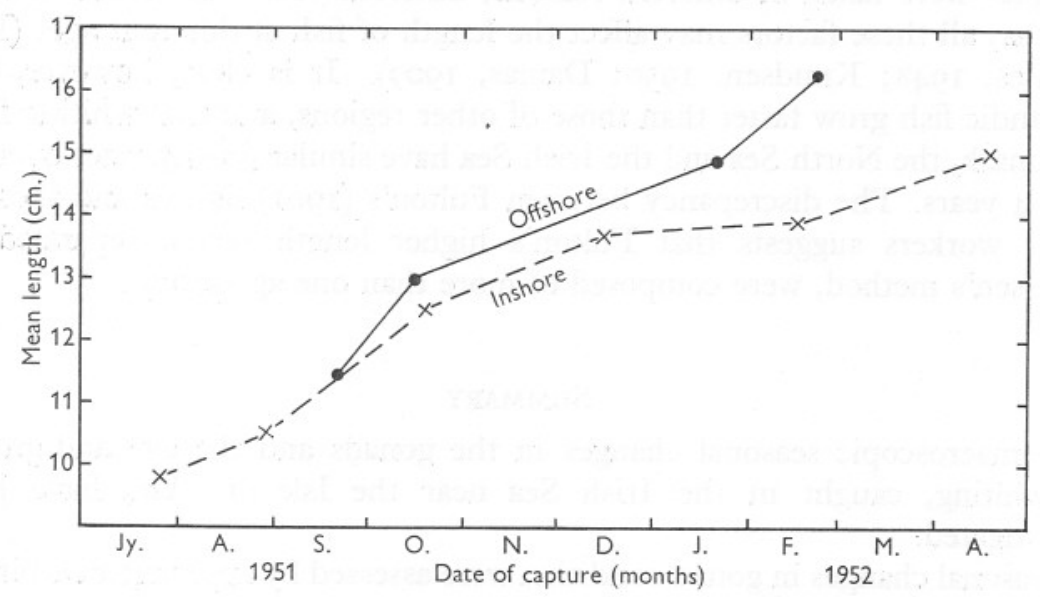

Text-fig. 6. Mean length of inshore and offshore whiting of r95 I brood.

Old fish (age-groups 5-7) were usually taken in the deepest water fished (40-45 fathoms), and the largest whiting are most commonly caught by local fishermen in deeper water. Ellis (I950) found a migration of older whiting to deep water in the North Sea. Thus the largest fish of the higher age-groups may not have been represented in the samples examined, and the calculated mean length for these age-groups may be too low.

The graphs (Text-fig. 4), expressing the increase in length of whiting with age, are based on data from samples collected in the two years I950 and I95I. A more accurate and direct statement of the growth of the fish would be obtained by sampling given year-classes in each year throughout their life span; this would involve a long-term programme. Short-term investigations, such as the present one, cannot give due weight to annual variations in growth; such variations, particularly in the growth of o-group fish (Knudsen, I950), 
are probably the cause of anomalies in growth calculations from age analysis. Table V, for example, shows irregularities in the annual increase in length, particularly between age-groups 2 to 3 and 3 to 4 , and similar irregularities are shown in the data of Damas (I909) and Desbrosses (I948).

The interpretation of Text-fig. 4 (p. III) as a growth curve of whiting in the Irish Sea must therefore be made with reservation; variations from the curve are to be expected if data are collected in different years, and if the fish examined are caught at different depths.

The results of previous work on age and growth in the whiting are set out in Table VI. Direct comparisons between investigations are unjustified, since few workers have shown separate growth rates for male and female fish, and samples were taken in different seasons, different years, and from different depths; all these factors may affect the length of fish at different ages (Desbrosses, I948; Knudsen, I950; Damas, 1909). It is clear, however, that Icelandic fish grow faster than those of other regions, and that whiting from Denmark, the North Sea and the Irish Sea have similar growth rates over the first 4 years. The discrepancy between Fulton's (I9OI) figures and those of other workers suggests that Fulton's higher length series, separated by Petersen's method, were composed of more than one age-group.

\section{SUMMARY}

The macroscopic seasonal changes in the gonads and the age and growth of whiting, caught in the Irish Sea near the Isle of Man, have been investigated.

Seasonal changes in gonad condition were assessed by applying an arbitrary classification of maturation into seven stages which are described.

Development of gonads from a 'resting' state to the 'full' (ripe) condition takes 3-4 months.

The whiting of this area have a long spawning period extending from February to June, with a peak in April.

Recovery from spawning is rapid.

The male whiting of this area may spawn for the first time at the end of their first year, but most fish spawn for the first time at the end of their second year or beginning of their third year of life, i.e. in age-group 2. Nearly all age-group 3 fish spawn.

The smallest spawning fish found were a male of $19 \mathrm{~cm}$. and a female of $21 \mathrm{~cm}$. length.

Few abnormalities in gonads were found.

Age determinations were made by means of otolith readings.

The translucent year-band in the otolith is laid down in age-group I fish in February, March or April, and in older fish between January and May. 
TABle VI. Length With Age of Whiting FRoM DifFerent Localities

\begin{tabular}{|c|c|c|c|c|c|c|c|c|c|c|c|c|c|c|c|c|c|c|}
\hline \multirow[b]{2}{*}{ Region } & \multirow[b]{2}{*}{ Authority } & \multirow{2}{*}{$\begin{array}{c}\text { Method of } \\
\text { age determination }\end{array}$} & \multirow{2}{*}{$\begin{array}{l}\text { Months in which } \\
\text { samples taken }\end{array}$} & \multicolumn{15}{|c|}{ Mean length in $\mathrm{cm}$. at each age-group (figures in brackets based on less than 5 fish) } \\
\hline & & & & I & $I_{\frac{1}{2}}$ & 2 & $2 \frac{1}{2}$ & 3 & $3 \frac{1}{2}$ & 4 & $4 \frac{1}{2}$ & 5 & $5 \frac{1}{2}$ & 6 & $6 \frac{1}{2}$ & 7 & $7 \frac{1}{2}$ & 8 \\
\hline Iceland & Saemundsson (1925) & Scales & Aug. & $18 \cdot 1$ & - & $27 \cdot 0$ & - & $39 \cdot 3$ & - & $46 \cdot 6$ & - & $51 \cdot 4$ & - & $54 \cdot 7$ & - & $59 \cdot 2$ & - & $(62.5)$ \\
\hline S. Norway & Damas (1909) & Measurements & Sept. & - & 24 & - & - & - & - & - & - & - & - & - & - & - & - & - \\
\hline Skagerrak & $\begin{array}{l}\text { Nybelin (I946 unpublished) } \\
\text { (cited by Desbrosses) }\end{array}$ & Otoliths & Mar. & $18 \cdot 9$ & - & $25 \cdot 4$ & - & $28 \cdot 7$ & - & 33 & - & - & - & - & - & - & - & - \\
\hline N. Denmark & Knudsen (1950) & $\begin{array}{l}\text { Measurements, scales } \\
\text { and otoliths }\end{array}$ & suly & 17.5 & - & $24 \cdot 2$ & - & $29 \cdot 9$ & - & - & - & - & - & - & - & - & - & - \\
\hline S. Denmark & Knudsen (1950) & $\begin{array}{l}\text { Measurements, scales } \\
\text { and otoliths }\end{array}$ & s July & 17.3 & - & $24 \cdot 6$ & - & $29 \cdot 9$ & - & $32 \cdot 5$ & - & - & - & - & - & - & - & - \\
\hline North Sea $54-59^{\circ} \mathrm{N}$. & Damas (1909) & Scales and otoliths & Nov. & - & $20 \cdot 2$ & - & 23.9 & - & 30.0 & - & $33 \cdot 7$ & - & $37 \cdot 3$ & - & (39) & - & - & - \\
\hline N. North Sea & Carr (1909) & Scales & Mar. & - & - & $25 \cdot 6$ & - & 27.9 & - & $29 \cdot 6$ & - & - & - & - & - & - & - & - \\
\hline N. North Sea & Fulton (1901, 1902) & Measurements & Oct.-Dec. & - & 23.7 & - & $31 \cdot 3$ & - & $46 \cdot 9$ & - & $53 \cdot 4$ & - & - & - & - & - & - & - \\
\hline N. North Sea & Thompson (1926) & Scales & - & 13.5 & - & $21 \cdot 5$ & - & 28 & - & - & - & - & - & - & - & - & - & - \\
\hline Irish Sea & This investigation & Otoliths & $\underset{\text { (Jan.-June) }}{\text { Spring }}$ & $\begin{array}{l}0 \\
0 \begin{array}{l}18.8 \\
+18.9\end{array}\end{array}$ & 二 & $\begin{array}{l}24 \cdot 6 \\
25 \cdot 4\end{array}$ & 二 & $\begin{array}{l}28 \cdot 1 \\
30 \cdot 0\end{array}$ & 二 & $\begin{array}{l}32 \cdot 2 \\
35 \cdot 2\end{array}$ & $=$ & $\begin{array}{l}34 \cdot 6 \\
4 \mathrm{I} \cdot \mathrm{I}\end{array}$ & 二 & $\begin{array}{l}38 \cdot 3 \\
46 \cdot 3\end{array}$ & 二 & $\begin{array}{l}(39 \cdot 3) \\
(49 \cdot 8)\end{array}$ & 二 & $(52 \cdot 5)$ \\
\hline English Channel & Thomsor & Scales & Winter & $7-18$ & - & $29-33$ & - & $32-42$ & - & $34-46$ & - & 49 & - & - & - & - & - & - \\
\hline Gulf of Gascony & Desbrosses (1948) & Otoliths & Winter & $\begin{array}{ll}0 \\
018 \cdot 1 \\
019 \cdot 0\end{array}$ & $\bar{z}$ & $\begin{array}{l}23 \cdot 4 \\
26 \cdot 7\end{array}$ & 二 & $\begin{array}{l}30 \cdot 3 \\
35 \cdot 2\end{array}$ & 二 & 40 & $=$ & $\begin{array}{l}(38 \cdot 2) \\
49 \cdot 3\end{array}$ & 二 & $\begin{array}{l}(46) \\
(59)\end{array}$ & 二 & 二 & 二 & $\overline{-}$ \\
\hline
\end{tabular}


The maximum age of the fish examined was 8 years.

The offshore stock in the area investigated consisted mainly of fish in age-groups I, 2, and 3, with lengths lying between I5 and $35 \mathrm{~cm}$.

There is a difference in growth rate between male and female fish; the females grow faster and reach a greater maximum length.

Both male and female fish reach a length of about $19 \mathrm{~cm}$. at the end of the first year. Thereafter female whiting increase in length 5 or $6 \mathrm{~cm}$. per year for five years, after which the rate of growth slows down. Males grow about $6 \mathrm{~cm}$. in their second year; the rate of growth then declines and is very small by the sixth year.

The limitations of the methods employed are discussed.

\section{REFERENCES}

BAL, D. V., I94I. Observations on spawning periods and key to pelagic eggs of fishes in Manx waters. Proc. Lpool. biol. Soc., Vol. 54, pp. I-8.

BulL, H. O., I928. The relationship between state of maturity and chemical composition of the whiting, Gadus merlangus L. F. Mar. biol. Ass. U.K., Vol. I5, pp. 207-18.

BurEaU DE CONSEIL, 1933. Atlas de Température et Salinité de l'eau de surface de la mer du Nord et de la Manche. 30 pp. Cons. Perm. Int. Explor. Mer, Copenhagen.

CARR, A. M., I909. Age determinations in the common dab, long rough dab and whiting. Rep. Northumb. Sea Fish. Comm., 1908-9, pp. 51-5.

CLARK, R. S., I920. The pelagic young and early bottom stages of teleosteans. F. Mar. biol. Ass. U.K., Vol. I2, pp. 159-240.

Cunningham, J. T., I889. Studies of the reproduction and development of teleostean fishes occurring in the neighbourhood of Plymouth. F. Mar.biol. Ass. U.K., N.S., Vol. I, pp. 10-54.

Damas, D., I909. Contribution à la biologie des Gadides. Rapp. Cons. Explor. Mer, Vol. ro, Special pt. B3, 277 pp.

Danish Meteorological Institute, I917. Monthly mean temperatures of the surface waters in the North Atlantic. Appx. to the Nautical Met. Annual, I9I7.

Davis, F. M., I934. Mesh experiments with trawls, I928-I933. Fish. Invest., Lond., Ser. 2, Vol. I4, No. I, 56 pp.

Desbrosses, P., I945. Le Merlan (Gadus merlangus L.) de la côte française de l'Atlantique. Rev. Trav. Off. Pêches marit., T. I3, pp. 177-95.

- 1948. Le Merlan (Gadus merlangus L.) de la côte française de l'Atlantique (deuxième partie). Rev. Trav. Off. Pêches marit., T. I4, pp. 7I-IO4.

EHRENBAUM, E., I936. Naturgeschichte und wirtschaftliche Bedeutung der Seefische Nordeuropas. Handb. Seefisch. Nordeurop., Bd. 2, 337 pp.

Ellis, R. W., 1950. Whiting. Analysis of British statistics. Ann. Biol., Copenhague, Vol. 6, 1949, pp. 106-9.

Fulton, T. W., I892. Observations on the reproduction, maturity and sexual relations of the food fishes. Rep. Fish. Bd Scot., Io, Pt. 3, pp. 232-43.

- rgor. On the rate of growth of the cod, haddock, whiting and Norway pout. Rep. Fish. Bd Scot., 19, Pt. 3, pp. 154-228.

- 1902. The rate of growth of sea fishes. II. Rep. Fish. Bd Scot., 20, Pt. 3, pp. $326-446$. 
GoKhale, S. V., I953. Seasonal histological changes in the gonads of the whiting, Gadus merlangus L. and the Norway pout, Gadus esmarkii N. in the Irish Sea. University of Liverpool, Ph.D. Thesis (to be published).

GrahaM, M., I924. The annual cycle in the life of the mature cod in the North Sea. Fish. Invest., Lond., Ser. 2, Vol. 6, No. 6, 77 pp.

- 1928. Studies of age-determination in fish. Part II. Fish. Invest., Lond., Ser. 2, Vol. II, No. 3, 50 pp.

HEINKE, F., I905. The occurrence and distribution of the eggs, larvae and various age-groups of the food-fishes in the North Sea. Rapp. Cons. Explor. Mer, Vol. 3, Appx. E, 39 pp.

Heinke, F. \& Ehrenbaum, E., I900. Eier und Larven von Fischen der deutschen Bucht. II. Die Bestimmung der schwimmenden Fischeier und die Methodik der Eimessungen. Wiss. Meeresunters., Abt. Helgoland, N.F., Bd. 3, pp. 127-332.

HicklING, C. F., I933. The natural history of the hake. Pt. IV. Age-determination and growth-rate. Fish. Invest., Lond., Ser. 2, Vol. I3, No. 2, I20 pp.

HJort, J., I910. Report on herring-investigations until January r910. Publ. Circ. Cons. Explor. Mer, No. 53, 174 pp.

Holt, E. W. L., I89I. Survey of fishing grounds. West coast of Ireland, I890. I-On the eggs and larvae of teleosteans. Sci. Trans. R. Dublin Soc., Vol. 4, Ser. 2, pp. 435-74.

— I893. Survey of fishing grounds. West coast of Ireland, I890-I89I. On the eggs and larval and post-larval stages of teleosteans. Sci. Trans. R. Dublin Soc., Vol. 5, Ser. 2, pp. 5-I2I.

Johnston, M., I938. Some methods of preparing teleost fish otoliths for examination. F. R. micr. Soc., Vol. 58, pp. II2-I9.

Jones, J. W. \& HyNES, H. B. N., I950. The age and growth of Gasterosteus aculeatus, Pygosteus pungitius and Spinachia vulgaris as shown by their otoliths. F. Anim. Ecol., Vol. I9, pp. 59-73.

KNudSEN, J., I950. Contributions to the biology of the whiting (Gadus merlangus L.) in the Danish waters. Rep. Danish biol. Sta., No. 52, pp. 27-40.

Menon, M. D., I950. Bionomics of the poor cod (Gadus minutus L.) of the Plymouth area. F. Mar. biol. Ass. U.K., Vol. 29, pp. 185-239.

Petersen, C. G. J., I895. Eine Methode zur Bestimmung des Alters und Wuches der Fische. Mitt. dtsch. SeefischVer., Bd. II, pp. 226-35.

Proudman, J., Lewis, H. M. \& Dennis, A. L., I937. On the temperature of the surface waters of the Irish Sea. Phil. Trans. A, Vol. 236, pp. 26I-302.

SAemundsson, B., I925. On the age and growth of the haddock (Gadus aeglefinus L.) and whiting (Gadus merlangus L.) in Icelandic waters. Medd. Komm. Havundersog, Kbh. Ser. Fisk., Bd. 8, pp. I-33.

Schмid, J., I909. The distribution of the pelagic fry and the spawning regions of the gadoids in the North Atlantic from Iceland to Spain. Based chiefly on Danish investigations. Rapp. Cons. Explor. Mer, Vol. Io, Special pt. B4, 227 pp.

Scott, A., I913. On the pelagic fish eggs collected in I913. Rep. Lancs. Sea-Fish. Labs, No. 22, pp. 26-36.

- I914. Report on fish eggs during 1914. Rep. Lancs. Sea-Fish. Lab., No. 23, pp. $2 \mathrm{I} 2-2 \mathrm{I}$.

ScotT, T., I906. Observations on the otoliths of some teleostean fishes. Rep. Fish. Bd Scot., 24, Pt. 3, Sci. Invest., pp. 48-82.

Steven, G. A., 1950. Nets. How to make, mend and preserve them. $128 \mathrm{pp}$. London.

Thompson, H., I926. Haddock biology III. Metabolism of the haddock and other gadoid fish in the aquarium. Rep. Fish. Bd Scot., 44, Pt. 3, No. 2, I4 pp. 
Thomson, J. S., I904. The periodic growth of scales in Gadidae as an index of age. F. Mar. biol. Ass. U.K., Vol. 7, pp. I-I09.

WALLACE, W., I907. Report on the growth rate of plaice in the southern North Sea as determined by the investigation of otoliths. 2nd Rep. Southern Area on Fishery and Hydrographic Investigations in the North Sea and adjacent Waters, Pt. I, London.

Williamson, H. C., I895. List of the pelagic ova, larvae, and young fish procured by the S.S. 'Garland' and boat 'Dalhousie'. Rep. Fish. Bd Scot., 13, Pt. 3, Sci. Invest., pp. 258-75.

1899. On the pelagic fish eggs and larvae of Loch Fyne. Rep. Fish. Bd Scot., 17, Pt. 3, Sci. Invest., pp. 79-131.

\section{EXPLANATION OF PLATE I}

Otoliths of whiting $\times 3 . \mathrm{A}$, top to bottom: $\delta, 9 \mathrm{~cm}$., July 1950, centre laid down; two $\delta^{\dagger} \delta^{\dagger}$, II cm., August 1950, new growth outside centre; $\delta^{t}, 18 \mathrm{~cm}$., May I950, concave and convex surfaces; $\hat{\alpha}, 22 \mathrm{~cm}$., May 1950, showing centre and first year band of extreme complexity. B: $\delta, 39 \mathrm{~cm}$., age-group 7 showing broad translucent bands with some 'doubling' of bands; $+50 \mathrm{~cm}$., age-group 6, a thick otolith with a keel-like process at the posterior end. C: $+9,49 \mathrm{~cm}$., age-group 7 showing centre, seven translucent year bands and a narrow opaque edge; the translucent bands show dark. 


\section{APPENDIX}

Table VII. Number and Length of Fish in each Age-group I950 AND I95I

\begin{tabular}{|c|c|c|c|c|c|c|c|c|}
\hline \multirow{2}{*}{$\begin{array}{l}\text { Length } \\
\text { (cm.) }\end{array}$} & \multicolumn{7}{|c|}{ No. of fish in each age-group } & \multirow[b]{2}{*}{ Tota } \\
\hline & I & 2 & 3 & 4 & 5 & 6 & 7 & \\
\hline & \multicolumn{8}{|c|}{ ô Whiting, I950 } \\
\hline I2 & I & - & - & - & - & - & - & I \\
\hline I3 & 3 & - & - & - & - & - & - & 3 \\
\hline 14 & 6 & - & - & - & - & - & - & 6 \\
\hline 15 & I3 & - & - & - & - & - & - & I3 \\
\hline 16 & 27 & - & - & - & - & - & - & 27 \\
\hline 17 & 45 & - & - & - & - & - & - & 45 \\
\hline 18 & 52 & 5 & - & - & - & - & - & 57 \\
\hline I9 & 52 & II & - & - & - & - & - & 63 \\
\hline 20 & 32 & 9 & - & - & - & - & - & $4 \mathrm{I}$ \\
\hline $2 \mathrm{I}$ & 23 & I3 & - & - & - & - & - & 35 \\
\hline 22 & 22 & I0 & - & - & - & - & - & 32 \\
\hline 23 & 9 & I6 & I & - & - & - & - & 26 \\
\hline 24 & 4 & I9 & - & - & - & - & - & 23 \\
\hline 25 & - & $2 \mathrm{I}$ & 8 & - & - & - & - & 29 \\
\hline 26 & - & I7 & 4 & - & - & - & - & $2 I$ \\
\hline 27 & - & IO & 9 & - & - & - & - & 19 \\
\hline 28 & - & I7 & IO & - & - & - & - & 27 \\
\hline 29 & - & 8 & 8 & 2 & - & - & - & 18 \\
\hline 30 & - & 5 & 7 & 2 & - & - & - & I4 \\
\hline $3 \mathrm{I}$ & - & 2 & 9 & 6 & - & - & - & 17 \\
\hline 32 & - & - & 3 & 6 & 3 & - & - & 12 \\
\hline 33 & - & - & - & - & - & I & - & I \\
\hline 34 & - & - & - & 3 & - & - & - & 3 \\
\hline 35 & - & - & - & I & 3 & I & I & 6 \\
\hline 36 & - & - & - & 2 & I & - & - & 3 \\
\hline 37 & - & - & - & I & I & 3 & I & 6 \\
\hline 38 & - & - & - & - & - & I & - & I \\
\hline 39 & - & - & - & I & - & - & I & 2 \\
\hline 40 & - & - & - & - & - & I & - & I \\
\hline & 289 & 163 & 59 & 24 & 8 & 7 & 3 & 553 \\
\hline an length & $19 \cdot 05$ & $24 \cdot 75$ & $28 \cdot 75$ & $33 \cdot 0$ & $34 \cdot 75$ & $37 \cdot 2$ & 37.5 & \\
\hline
\end{tabular}


TABLE VII (cont.)

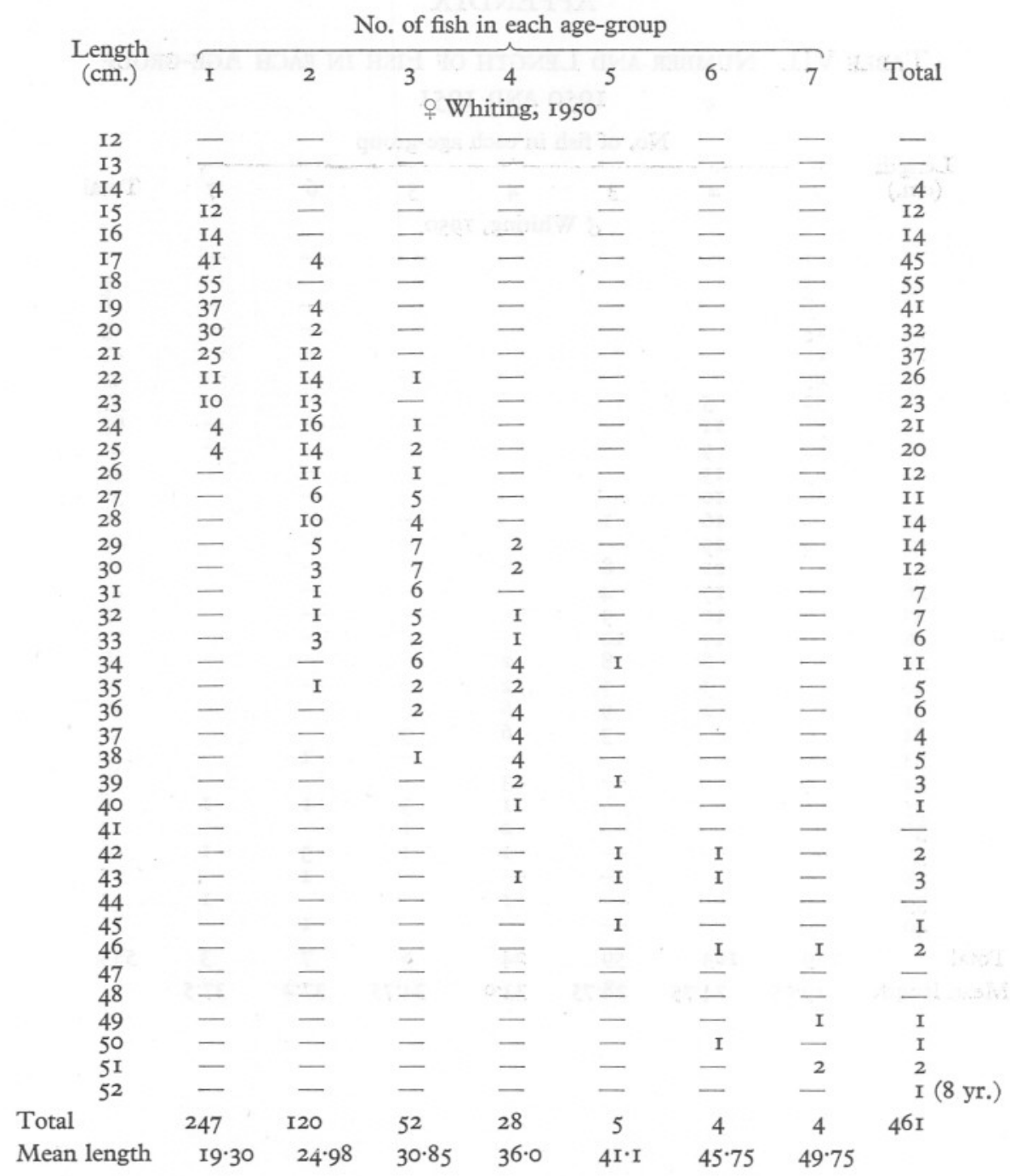




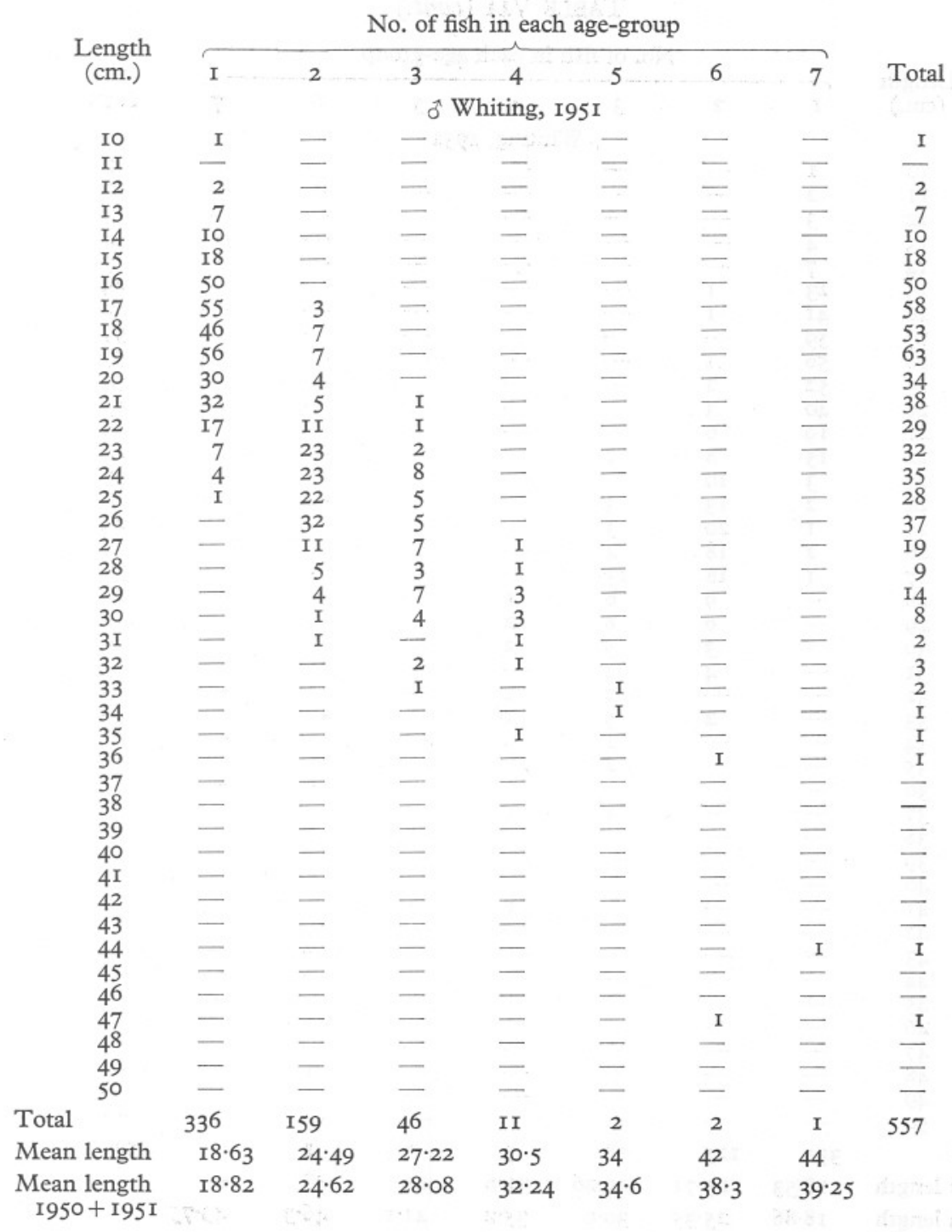




\begin{tabular}{|c|c|c|c|c|c|c|c|c|}
\hline \multirow{2}{*}{$\begin{array}{l}\text { Length } \\
\text { (cm.) }\end{array}$} & No. of fish in each age-group & \multicolumn{7}{|c|}{ TABLE VII (cont.) } \\
\hline & I & 2 & 3 & 4 & 5 & 6 & 7 & Total \\
\hline \multicolumn{9}{|c|}{ q Whiting, I95 I } \\
\hline Io & I & - & - & - & - & - & - & I \\
\hline II & 2 & - & - & - & - & - & - & 2 \\
\hline I2 & 3 & - & - & - & - & - & - & 3 \\
\hline I3 & 4 & - & - & - & - & - & - & 4 \\
\hline I4 & 7 & - & - & - & - & - & - & 7 \\
\hline I5 & 23 & I & - & - & - & - & - & 24 \\
\hline I6 & $4 I$ & I & - & - & - & - & - & 42 \\
\hline I7 & 59 & - & - & - & - & - & - & 59 \\
\hline I8 & 56 & I & - & - & - & - & - & 57 \\
\hline I9 & 52 & 2 & - & - & - & - & - & 54 \\
\hline 20 & 40 & 3 & - & - & - & - & - & 43 \\
\hline $2 \mathrm{I}$ & I9 & 6 & - & - & - & - & - & 25 \\
\hline 22 & I5 & 8 & I & - & - & - & - & 24 \\
\hline 23 & 3 & IO & - & - & - & - & - & 13 \\
\hline 24 & 2 & I3 & 3 & - & - & - & - & I8 \\
\hline 25 & I & 20 & 3 & - & - & - & - & 24 \\
\hline 26 & 2 & I8 & 4 & - & - & - & - & 24 \\
\hline 27 & I & I8 & 13 & - & - & - & - & 32 \\
\hline 28 & - & 9 & 6 & I & - & - & - & I6 \\
\hline 29 & - & 6 & 8 & 2 & - & - & - & I6 \\
\hline 30 & - & 3 & 5 & 2 & - & - & - & IO \\
\hline $3 I$ & 一 & 4 & 4 & - & - & - & - & 8 \\
\hline 32 & - & - & 2 & I & - & - & - & 3 \\
\hline 33 & - & 2 & 5 & I & - & - & - & 8 \\
\hline 34 & - & - & I & - & - & - & - & I \\
\hline 35 & - & - & 2 & - & - & - & - & 2 \\
\hline 36 & - & - & - & - & - & - & - & - \\
\hline 37 & - & - & I & I & - & - & - & 2 \\
\hline 38 & - & - & - & - & - & - & - & - \\
\hline 39 & - & - & - & - & - & - & - & 一 \\
\hline 40 & - & - & - & - & - & - & - & - \\
\hline $4 \mathrm{I}$ & 一 & - & - & I & I & - & - & 2 \\
\hline 42 & - & - & - & - & - & - & - & - \\
\hline 43 & - & - & - & - & - & - & - & - \\
\hline 44 & - & - & - & - & - & - & - & - \\
\hline 45 & - & - & - & - & - & - & - & - \\
\hline 46 & - & - & - & - & - & - & - & - \\
\hline 47 & - & - & - & - & - & - & - & - \\
\hline 48 & - & - & - & - & - & I & - & I \\
\hline 49 & - & - & - & - & - & - & - & - \\
\hline 50 & - & - & - & - & - & - & - & - \\
\hline Total & $33 I$ & 125 & $5^{8}$ & 9 & I & I & - & 525 \\
\hline Mean length & I8.53 & $25 \cdot 71$ & $29 \cdot 26$ & $32 \cdot 6$ & $4 \mathrm{I}$ & 48 & - & \\
\hline $\begin{array}{l}\text { Mean length } \\
\text { I950+ I95I }\end{array}$ & I 8.86 & $25 \cdot 35$ & $30 \cdot 0$ & $35 \cdot 2$ & $4 I \cdot I$ & $46 \cdot 3$ & $49 \cdot 75$ & \\
\hline
\end{tabular}

